自制 $\mathrm{AgClO}_{4}$ 时带入的杂质, 说明它对 $\mathrm{Ag}^{+}$

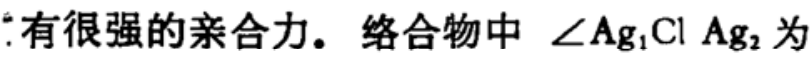
$71^{\circ}$, 偏离 $\mathrm{Cl}^{-} s p^{3}$ 杂化应取的 $109^{\circ}$ 甚多, 由 此造成的张力使得 $\mathrm{Ag}-\mathrm{Ag}$ 间距为 $3.181 \AA$, 大于另一同样由 $\mathrm{dppm}$ 桥连但不带氯桥的 [ $\left.\mathrm{Ag}(\mathrm{dppm}) \mathrm{NO}_{3}\right]_{2}$ 中的 $\mathrm{Ag}-\mathrm{Ag}$ 间距 $(3.089 \AA)$. 络合物中的 $\mathrm{Ag}(\mathrm{I})$ 为了满足 18 电子的满壳 层, 还各与一个吡啶溶剂分子结合, 呈扭曲的 四面体配位, 其中 $\angle \mathrm{PAgP}$ 平均为 $129.4^{\circ}$, $\angle \mathrm{ClAgN}$ 平均为 $97.8^{\circ}$.

阳离子骨架 $\mathrm{Ag}_{2} \mathrm{P}_{4} \mathrm{C}_{2}$ 呈扭曲的船 式八
元环构型, 两个亚甲基位于船头, 其中每个 $\mathrm{dppm}$ 与两个 $\mathrm{Ag}^{+}$及 $\mathrm{Cl}^{-}$则共构成了两个 船式的六元环. 两个端基吡啶被扭曲到氯桥 的同侧, 而两个 dppm 则处于远离氯桥的另 侧. 这种W型构型是桥连双核络合物 $\mathrm{A}$ 型结 构的一种变形,它在理论上是较稳定的,但实 际上具有这种构型的却只有少数几个, 这与 空间位阻有关.

\section{张 张 畋 黄明生 郑兰苏 杨华㯖 （屏门大学化学系, 圆门 361005)}

\title{
可可西里1973 年火山活动质疑
}

1981 年, T. Simkin 等编著的世界火 山 (《Volcanoes of the World》) 一书出版, 书中收集了有案可查的近万年以来世界各地 火山的资料. 书中列出了我国可可西里地区 的一个无名火山, 其地理位置为北纬 $35.85^{\circ}$, 东经 $91.70^{\circ}$, 海拔 $5200 \mathrm{~m}$,于 1973 年 7 月 16 日在原有破火山口东北沿的再次喷发. 可可 西里地处青藏高原腹地, 平均海 拔 $5000 \mathrm{~m}$, 高寒缺氧, 荒无人迹, 是科学研究的空白区. 这个“活火山”的报道, 更使这块处女地蒙上 了一层神奇的面纱.

国家可可西里综合科学考察队两年的实 地调查结果表明, 该区不存在 1973 年形成的 活火山.

1990 年, 可可西里综合科学考察正式展 开, 寻找这个活火山被列为考察重点之一. 为了更科学、更全面地解决活火山存在与否 的问题, 我们扩大了调查范围, 增加了考察内 容. 经过认真细致的工作, 我们从以下三方
面提出该区 1973 年确实没有火山活动 的 证 据.

首先, 没有任何新的火山活动产物,包括 火山地貌、火山喷发产物等都不存在; 其次, 地面没有火山作用的痕迹, 既见不到地温异 常点, 山顶终年积雪形成的冰帽、小型冰川也 没有融化或减少; 第三, 在 1971-1974 年几 年里, 该区正在进行航空照片地面标绘工作, 无论从已出版的地形图上还是从当年的有关 报道里均没有火山活动的记载. 因此, 可以 肯定地讲, 可可西里地区 1973 年没有火山活 动,不存在活火山.

当然, 由于可可西里地区新生代以来构 造岩浆作用比较强烈, 第三纪的火山岩十分 发育, 在区内还发现了温度超过当地沸点的 沸泉, 这些对地质学家仍具有很大的吸引力. 该区还有许多奥秘等待人们去认识去探索.

郑 祥 身

(中国科学院地质研究所, 北京 100029) 